6. HARPER, F. 1945 Extinct and vanishing mammals of the old world. Special Publication 12. American Committee for International Wildlife Protection. New York.

7. IUCN 1972 Red Data Book: Mammalia. IUCN, Morges, Switzerland.

8. MAYDON, H.C. ed. 1932 Big game shooting in Africa. London.

9. POWELL-COTTON, P.H.G. 1902 A sporting trip through Abyssinia. London.

10. STAEHL 1975 Report on Simien Mountains National Park. In World Wildlife Fund Yearbook 1974-5. Morges, Switzerland.

11. TYLER, S. 1975 The Simien Fox. Wildlife 17 564-5.

12. YALDEN, D.W. 1973 Prey of the Abyssinian long-eared owl, Asio abyssinicus. Ibis 115 605-606.

13. YALDEN, D.W. 1975 Some observations on the giant mole rat Tachyoryctes macrocephalus (Rüppell, 1842) (Mammalia, Rhizomyidae) of Ethiopia. Mon. zool. ital. 15 275-303.

Dr Patrick A. Morris, Royal Holloway College, Englefeld Green, Surrey TW20 9TY.

\title{
Man Pressure Again
}

\section{G. C. L. Bertram}

In 1963 Oryx published an article by Dr Bertram called Man Pressure. This second article returns to the theme, the argument being now reinforced by the addition in the interval of another 1000 million people to the world's population. At this rate what hope have we of conserving the other species that share the planet, and without them what hope is there for human survival?

'Man Pressure' described the basic and overwhelming pressure of ourselves upon all that great variety of animal and plant species, the glory of our planet, which we seek to preserve and conserve for an extended future. Since then, in a mere fourteen years, almost 1000 million more people have been added to the world in competition with those other species which we use, enjoy and hold in trust. Our species now numbers over 4000 million, all aspirants to a sufficiency of food and a level of material well-being far higher than all but the relatively few already enjoy (and some squander to excess). Our population explosion is like nuclear warfare in that the enormity of each is so great that many seek to forget the consequences, and the two are connected because in some degree the fervour generated by the former increases the probability of the latter, and the second may well finally 'solve' the first. But both enormities are still within our control if we will but exert ourselves sufficiently and rationally. If we do not, all that we hold dear in quality of life, and even in life itself may end. Decades of great danger are inevitable but the possibility of success must spur us on.

The fifth billion of human kind will take only another eleven years to arrive and we shall be over 6000 million by the turn of the century and still vastly proliferating. Robert S. McNamara, President of the World Bank, a realist but one not without hope of ultimate success, has recently provided us with an excellent conspectus of human demographic affairs. So important is the issue and succinct his summary that I quote: 'It now appears that a significant decline in fertility may have at last begun in the developing countries. The data are not yet fully conclusive ... (but) ... if . . continued ... then what we are seeing here is something of historic importance. It would mean that the period of rapid acceleration in the rate of growth of the world's population has finally 
reached its peak and is now definitely moving downwards towards stabilisation. But welcome as this is, the fact remains that the current rate of decline in fertility in the developing countries is too slow to avoid their ultimately arriving at stationary populations far in excess of acceptable levels . . the global population may not stabilize below 11 billion.* That would be a world none of us would want to live in'. But Mr McNamara, demographer and economist, is not a biologist. In this particular address (to the Massachusetts Institute of Technology) he made no attempt to survey the feeding and provisioning of the masses: he was extrapolating from present figures.

More realistically, evidence and comparison all point to a 'biological crash' in our own species within the lifetime of some already born; whether the most likely agency of that crash be starvation, mutant viruses, nuclear warfare or otherwise, may be debatable. This is what we all must seek strenuously to avoid, but those yet conscious of the realities are so small a proportion of the whole. The 'crash' may be world-wide (certainly in repercussions) or it may primarily afflict particular geographical areas. Perhaps the coincidence of a monsoon failure in India and a few years of drought in North America would be a proximate cause.

This then is the framework of reality within which in our zeal, both personal and banded together in dedicated conservation societies, we seek to keep in being the vast range of other species which share our planet. The wider spreading consciousness of need must be an encouragement, as must the adhesion of progressively more countries to IUCN and other agencies. But the slowness of the advance of awareness and of action almost everywhere is frightening. We all, in the Fauna Preservation Society, are aware of so many instances where it is not knowled ge which is in short supply but lack of known sensible practices. The parlous state of the fisheries of the world is a prime example, to speak no further here of those countless instances in many lands where species-protective legislation exists but is not enforced.

A further measure of the danger, (but of course including an element of advance) is the new insight which requires that ecosystems be preserved and not just particular species in isolation. Such thought had scarcely begun in 1963, nor had the wide consciousness of gross pollution problems. To what new modes of thought will we be brought by the next addition of near a billion to our total in the coming decade?

Surgeons are said to take 'heroic' measures, cutting away the moribund by amputation. Are we as conservationists to be forced into a like frame of mind and action? To quote Mr McNamara, the realist, on Coercion: 'A number of governments are moving in the direction of coercion already' (in attempting to limit populations). 'Some have introduced legal sanctions to raise the age of marriage. A few are considering direct legal limitations on family size and sanctions to enforce them. No government really wants to resort to coercion in this matter. But neither can any government afford to let population pressures grow so dangerously large that social frustrations finally erupt into irrational violence and civil disintegration. That would be coercion of a very different order. In effect it would be nature's response to our own indifference'. India, land of myriads, has recently reacted against a maladroit coercion, yet is the home of Project Tiger! Heroism (in the surgeons' sense) and realism are the constant need.

\footnotetext{
* The billion as here used is a thousand million.
} 
Our world-wide, large, omnivorous species now doubles its total in a generation, the result of an admirable beneficence and caring for people at a distance, together with the application of much new sanitary knowledge. Our increase is not planned, but our eventual decrease must be if we are to avoid or minimise the otherwise inevitable crash. Let it be trumpeted loud and clear, as part of the education of all, that there are no positive advantages in any further increase in the numbers of our own species; on the contrary, the possibility of the good life, more widely spread, fades with every added million. The political realist, too, may fear that the chances for true democracy diminish as total national populations rise. The psychological impact upon the individual of living at high population densities in arid cities is deleterious long before the stage of reproduction on the pavements, as in Calcutta. Yet, it may be that the more the masses cram themselves into the cities, the slightly greater is the chance of species conservation elsewhere.

\section{The Largest Biomass Ever}

To feed twice as many people at a more adequate level requires a near doubling of the area of production despite ingenious expedients, and even if we can utilise tens of millions of tons of krill from the Southern Ocean. That doubling is a measure of the decrease that will be needed in areas that now support most other animal and plant species. The world's tropical forests are now disappearing, under human impact, at the almost unbelievable rate of 20 hectares per minute, according to Gren Lucas of Kew. It is these desperately threa tened tropical rain forests and the equally threatened coral reefs which in their different ways contain the maximum variety of co-existent species.

Never before in world history has there been so large a co-existent biomass of any land animal. Our human biomass, perhaps today at 160 million tons (at 25 of us on average to the ton), may only be surpassed by the krill of the Southern Ocean, if some comparison must be drawn. But we are imbued with hope and expectations, and endowed with powers over other species. Here lies total responsibility in our utterly unique situation.

A further real problem is that the rate at which we must react, so as both to conserve ecosystems and limit our own numbers, is unlikely to be achieved, and we are faced with the age-old problem of freedom versus control. To achieve change through education, in freedom, is commonly so slow in comparison with coercion; but coercion is not acceptable to freedom-loving people. There lies paradox. Speed comes only with desperation, and that may be too late.

Our predicament is indeed multifactorial in origin, but our own population increase is dominant. Many expedients are requisite in a ttempting 'cure', all of them significant, but the limitation of our own species is paramount. What profit is there in the mere survival of underfed hosts of humans in a deteriorating environment? Surely the new insight demands an enhanced quality of life for fewer people (in their fascinating and diverse ethnic variety) in a world furbished with all the species of animals and plants and intricate ecosystems of which it is capable. This is not selfishness, but sense and healthy vision.

Dr Bertram is a member of the FPS Council and Chairman of the Sirenia Specialist Group of the IUCN Survival Service Commission. 